\title{
PENERAPAN STRATEGI MIND MAPPING SEBAGAI UPAYA PENINGKATAN KEMAMPUAN MAHASISWA DALAM MENULIS ARTIKEL ILMIAH
}

\author{
Musaffak \\ Fida Pangesti \\ Universitas Muhammadiyah Malang \\ musaffak@umm.ac.id
}

\begin{abstract}
ABSTRAK
Penelitian ini bertujuan untuk mendeskripsikan kemampuan mahasiswa dalam menulis artikel ilmiah dengan penggunaan strategi mind mapping. Pendekatan penelitian ini adalah penelitian deskriptif kualitatif. Artikel ilmiah yang digunakan oleh peneliti sebagai data dalam penelitian ini adalah 1 (satu) kelas. Artikel ilmiah yang sudah didapatkan dari mahasiswa diolah dan dianalisis. Berdasarkan hasil analisis penelitian ini, yaitu kemampuan mahasiswa dalam menulis artikel ilmiah dengan menggunakan strategi mind mapping meningkat. Pertama, menunjukkan kemenarikan, kesesuaian judul dengan isi, penulisan ejaan sesuai, dan diksi sesuai, menunjukkan isi artikel, makna khusus dalam menulis judul artikel ilmiah. Kedua, menunjukkan kelengkapan isi, kesesuaian isi, gagasan runtut, penulisan ejaan sesuai, penulisan tanda baca sesuai, diksi sesuai, kalimat sesuai, dan paragraf sudah padu dalam menulis pendahuluan artikel ilmiah. Ketiga, menunjukkan kelengkapan substansi permasalahan, kesesuaian antara urgensi masalah dengan isi, gagasan runtut, penulisan ejaan sesuai, penulisan tanda baca sesuai, diksi sesuai, kalimat sudah efektif, dan paragraf sudah padu dalam menulis pembahasan artikel ilmiah. Keempat, menunjukkan kelengkapan substansi permasalahan, kesesuaian isi dengan intisari permasalahan, gagasan runtut, penulisan ejaan sesuai, penulisan tanda baca sesuai, diksi sesuai, kalimat sudah efektif, kohesi, dan koherensi dalam menulis kesimpulan artikel ilmiah. Kelima, menunjukkan penulisan ejaan sesuai, penulisan tanda baca sesuai bahasa Indonesia, kesesuaian dengan penulisan daftar pustaka, dan kelengkapan unsur penulisan daftar pustaka dalam menulis daftar pustaka artikel ilmiah.

Kata kunci: artikel ilmiah, kemampuan menulis, strategi mind mapping
\end{abstract}

\section{ABSTRACT}

This study aims to describe the ability of students to write scientific articles with the use of mind mapping strategies. The approach of this research is qualitative descriptive research. Scientific articles used by researchers as data in this study are 1 (one) class. Scientific articles that have been obtained from students are processed and analyzed. Based on the results of the analysis of this study, namely the ability of students to write scientific articles using mind mapping strategies increases. First, it shows attractiveness, the suitability of the title with the content, the suitability of spelling writing, and the accuracy of diction, showing the contents of the article, the special meaning in writing the title of a scientific article. Second, show the completeness of the content, suitability of content, coherent ideas, suitability of spelling writing, conformity of punctuation writing, suitability of diction, suitability of sentences, and coherent paragraphs in writing preliminary scientific articles. Third, it shows the completeness of the substance of the problem, the compatibility between the urgency of the problem with the content, coherent ideas, the suitability of spelling writing, the suitability of punctuation writing, the accuracy of diction, effective sentences, and coherent paragraphs in writing scientific article discussions. Fourth, show the completeness of the substance of the problem, the suitability of the content with the essence of the problem, coherent ideas, suitability of spelling writing, conformity of punctuation writing, diction accuracy, effective sentences, cohesion, and coherence in writing scientific article conclusions. Fifth, it shows the suitability of spelling writing, the suitability of Indonesian punctuation writing, compatibility with bibliography 
Volume 3, No. 2, September 2018

writing, and the completeness of the elements of writing bibliography in writing bibliography of scientific articles.

Key words: mind mapping, scientific article, writing competence

\section{PENDAHULUAN}

Kemampuan menulis artikel ilmiah merupakan kegiatan yang sering diterima mahasiswa dari dosennya. Dengan menulis artikel ilmiah, diharapkan mahasiswa dapat meningkatkan kemampuan menulisnya, sehingga berimbas pada semua tugas yang diterimanya. Di samping itu, tagihan tugas untuk setiap matakuliah biasanya berbentuk artikel ilmiah. Proses menjadikan mahasiswa berkualitas dapat diawali dengan pembinaan dan pengembangan kemampuan menulis artikel ilmiah. Kemampuan menulis artikel ilmiah merupakan kegiatan yang dapat mengasah kemampuan berpikir kritis mereka dengan cara penuangan dalam bentuk tulisan berkualitas.

Berdasarkan hasil refleksi awal, diketahui bahwa mahasiswa masih banyak mengalami kesulitan dalam menguasai kemampuan menulis artikel ilmiah. Kesulitan itu berupa kurangnya kemampuan mahasiswa dalam penulisan judul pada aspek kemenarikan judul, kesesuaian, ejaan, dan diksi yang digunakan; penulisan pendahuluan pada aspek kesesuaian pendahuluan, keruntutan, kelengkapan, ejaan, tanda baca, diksi, kalimat sudah efektif, dan paragraf sudah padu; penulisan pembahasan pada aspek kesesuaian pembahasan, keruntutan, kelengkapan, ejaan, tanda baca, diksi, kalimat sudah efektif, dan paragraf sudah padu; penulisan penutup pada aspek kesesuaian penutup, kelengkapan, ejaan, tanda baca, diksi, kalimat sudah efektif, dan paragraf sudah padu; dan penulisan daftar pustaka pada aspek ejaan daftar pustaka, tanda baca, kesesuaian, dan kelengkapan daftar pustaka. Semua itu terjadi karena strategi pembelajaran selama ini kurang bervariasi dan masih banyak pengajar yang menggunakan teknik konvensional yang lebih mementingkan hasil akhir penulisan dari pada proses menghasilkan sebuah tulisan ilmiah yang berkualitas. Teknik seperti ini kurang mampu menggali kreativitas mahasiswa sehingga pola pikir mereka cenderung bagaimana menyelesaikan dengan cepat tanpa berpikir menyelesaikan dengan cara dan hasil yang lebih baik.

Selama ini ada kecenderungan mahasiswa setiap menulis artikel ilmiah lebih berorientasi pada tebal halaman dan panjang karangan, tidak pada signifikansi masalah, kelogisan isi, dan kejelasan pengorganisasian. Supaya mahasiswa mampu menulis artikel melalui tahapan yang terganisir dan berkualitas.

Pada dasarnya, kekurangan penulisan artikel ilmiah biasanya terletak pada penulisan tata bahasa dan teknik menulis yang prosedural (Blumner, 2008, hal. 21). Ada kecenderungan bagi penulis pemula sering melakukan kesalahan dalam hal kemenarikan isi, kesesuaian ini, penulisan ejaan, tanda baca, diksi, kelengkapan, keruntutan, kalimat sudah efektif, dan 
paragraf sudah padu serta tulisan yang tidak konsisten dalam menyajikan isi tulisan. Hal itu karena tidak ada singkronisasi tulisan dengan pedoman penulisan yang berlaku. Menulis karya ilmiah supaya di dalamnya terdapat kalimat yang koheren dan efektif sangat sulit. Menulis seperti itu bisa dilakukan dengan cara menulis terus-menerus. Cara nalar dan perolehan bahan bacaan yang banyak menentukan kandungan isi tulisan (Kellog, 2008, hal. 2).

Artikel ilmiah adalah karya cipta yang di dalamnya mengandung topik yang berkaitan dengan tugas perkuliahan bagi mahasiswa yang diperesentasikan dalam kegiatan seminar atau lokakarya (Sudarmanto, 2007, hal. 237). Artikel ilmiah juga merupakan karya yang di dalamnya topik khusus yang mengandung pengetahuan. Artikel ilmiah merupakan bentuk karya ilmiah yang terikat dengan unsur objektif, faktual, taat azaz, dan kekinian. Bagus tidaknya sebuah artikel tergantung dari pengorganiasasian ruang lingkup cakupan tema, isi, dan simpulan (Tim Dosen UM, 2010, hal. 79).

Selain itu, artikel ilmiah adalah karya ilmiah yang dibuat sebagi bentuk luaran tugas matakuliah yang biasanya dikerjakan secara individu atau kelompok yang harus dipresentasikan di depan teman-temannya. Artikel ilmiah dapat juga dari hasil penelitian individu atau kelompok yang penyajiannya pada kegiatan seminar dan lokakarya. Artikel ilmiah merupakan jenis karya tulis yang ketebalannya antara 10-25 halaman dengan spasi 1,5 (Nasucha, Rohmadi, Wahyudi, \& Kusumawati, 2009, hal. 59).
Judul merupakan bagian dari kepala artikel ilmiah yang juga menjadi sentral atau pokok untuk melihat isi keseluruhan artikel yang dibuat. Dalam pembuatan judul artikel ilmiah terlebih dahulu harus memperhatikan topik yang diangkat, kekinian, dan berdampak positif terhadap pembaca. Kemenarikan sebauah judul artikel ilmiah terletak pada jumlah kata dan diksi yang digunakan dalam sebuah judul. Semakin panjang sebuah judul, maka semakin sempit kajian masalah yang dibahas, sehingga harus pendek antara 10-15 kata (Haryanto \& dkk, 2000, hal. 59-60).

Dalam penulisan judul harus memperhatikan kemenarikan, kelugasan, kelogisan, kesesuaian, keringkasan, dan prosudur yang diberlakukan. Penulisan judul huruf harus memperhatikan mana yang memakai huruf kapital dan mana yang memakai huruf nonkapital. Pada setiap kata huruf pertama menggunakan huruf kapital, kecuali pengunaan kata depan seperti di, ke, dari, dan, yang, dan untuk yang bukan di awal judul. Penting atau tidaknya sebuah tulisan dapat diketahui melalui judul. Ketentuan menulis judul meliputi (1) sesuai dengan penulisan ejaan dan tanda baca; (2) memperhatikan penggunakan huruf capital dan nonkapital; dan (3) tidak diakhiri diakhiri dengan tanda baca titik (Supadi, 2007, hal. 17).

Penulisan pendahuluan merupakan bagian dari artikel ilmiah yang berisi tentang gambaran umum terkait topik yang dibahas. Di dalam pendahuluan ini, penulis harus menyajikan alasan atau urgensi permasalahan artikel ilmiah. 
Selain itu, pendahuluan berisi ulasan pengantar atau pembuka untuk pembaca sebelum melihat atau membaca secara detail terkait isi yang dibahas. Fungsi pendahuluan adalah untuk memberi gambaran awal terkait isi yang akan dibahas. Pendahuluan harus bisa meyakinkan pembaca terkait permasalahan yang dibahas. Kebanyakan orang menganggap bahwa bagian pendahuluan adalah bagian tersulit dalam menulis karya ilmiah, khususnya artikel. Penulis pemula banyak yang mengeluh karena tidak tahu harus memulai tulisan dengan bagaian mana. Cara yang sesuai untuk memulai membuat bagian pendahuluan adalah sering menulis, tahu pola, dan langkahnya (Adnan, 2005 , hal. 25).

Unsur yang terkandung dalam penulisan artikel ilmiah biasanya memuat latar belakang, rumusan masalah, dan tujuan masalah. Dalam latar belakang biasanya berisi gagasan yang bersifat teoretis dan praktis. Rumusan masalah berisi poin pertanyaan terkait masalah yang diangkat. Adapun tujuan berisi kalimat pernyataan terkait rumusan masalah.

Pembahasan dalam artikel ilmiah berisi tentang ulasan jawaban dari semua permasalahan yang dimunculkan pada bagian pendahuluan. Pembahasan menjadoi inti dari sebuah artikel ilmiah. Pembahasan harus menguraikan permasalahan yang sudah dipilih secara urut. Di samping itu, pembahasan juga harus menampilkan kutipan sebagai penguat gagasan pada setiap permasalahan. Penjelasan detail terkait permasalahan dapat dilihat pada bagian pembahasan. Pembahsan yang baik minimal menjawab semua permasalahan (Tim Dosen UM, 2010, hal. 83). Kualitas tulisan dapat terlihat melalui dari semua pemaparan pembahasan. Bahasa di dalamnya saling terkait dan komunikatif, sehingga harus menggunakan bahasa yang baik dan benar serta berpedoman pada bahasa Indonesia yang berlaku. Bahasa yang tersusun dalam kalimat dan paragraf juga harus menggunakan nalar kritis, kohesi, koherensi, kalimat efektif, dan mengunakan paragraf yang padu.

Penutup berisi kesimpulan, intisari, atau jawaban dari permasalahan yang diangkat dalam penulisan artikel ilmiah. Penutup menjadi penanda bahwa penulisan artikel ilmiah itu berakhir. Kesimpulan sama seperti rangkuman pembahasan (Tim Dosen UM, 2010, hal. 84).

Daftar pustaka merupakan bagian dari artikel ilmiah yang di dalamnya berisi daftar buku, artikel ilmiah, artikel, dan bahan lainnya yang dikutip baik secara langsung maupun tidak langsung sesuai pedoman yang berlaku. Merujuk merupakan bagian dari karakter penulisan artikel ilmiah. Unsur menulis daftar pustaka terdiri dari penulisan nama pengarang (dibalik bagi yang memiliki jumlah kata lebih dari satu pada kata terakhir), tahun terbit (gunakan tahun terbaru), judul buku (dicetak miring dan menggunakan huruf kapital dari setiap huruf awal), kota terbit, dan nama penerbit. Unsur-unsur tersebut beragam tergantung jenis sumber pustaka yang dikutip (Tim Dosen UM, 2010, hal. 106). 
Apabila menggunakan gagasan sendiri pada tulisan di pendahuluan dan di pembahasan baik secara langsung ataupun tak langsung, maka tidak perlu mendaftar sumber pustaka di daftar pustaka.

Yang menjadi perhatian lebih dalam menulis artikel ilmiah selain di atas adalah strategi pembelajaran yang digunakan. Salah satu strategi yang cocok untuk menulis karya tulis artikel ilmiah adalah strategi mind map. Strategi mind map adalah cara, pendekatan, atau teknik untuk memunculkan ide, gagasan, informasi untuk membuat perencanaan sebuah tulisan. Strategi ini bisa mengasah otak yang tidak diaktifkan secara maksimal dan strategi ini dapat memunculkan informasi penting dari luar otak ke dalam otak (Susi, 2010, hal. 4). Strategi mind mapping lebih banyak mengandalkan daya nalar secara mendalam. Kekreatifan diperlukan dalam menggunakan strategi ini. Secara alami, kinerja otak akan lebih maksimal menggunakan strategi ini. Strategi ini banyak melibatkan visual gambar atau grafis untuk memperkuat karakter poin atau kata kunci yang dimunculkan.

Strategi mind mapping adalah pendekatan yang dapat digunakan untuk merangkai kerangka tulisan dengan menggunakan media grafis dan gambar sesuai karakter poin-poin yang dijadikan kata kunci. Dengan menggunakan strategi ini, maka daya nalar kita semakin terasah (Abdurrahman, 2000, hal. 153-154). Strategi ini dapat membangkitkan sel-sel otak yang lemah dan akan menimbulkan rasa menyenangkan, nyaman, dan inovasi serta rasa puas karena hasil yang dicapai maksimal. Strategi mind mapping merupakan strategi untuk memunculkan ide-ide baru, kekinian, singkat, faktual, dan hasilnya tersusun secara terorganisir. Dengan strategi ini membuat orang yang menggunakannya mudah dalam mengidentifikasi ide-ide atau poin pokok secara secara jelas dan mendalam. perencanaan suatu kerangka dapat terbentuk dengan baik (Bermawy \& dkk, 2009, hal. 188).

Ketika mahasiswa menerapkan strategi ini maka mereka sangat mudah untuk membuat artikel ilmiah. Menulis artikel ilmiah menjadi mudah dengan mengawali perencanaan konsep dalam bentuk mind mapping. Namun, kemudahan itu tidak ada gunanya manakala tidak merepkan stategi ini dengan baik. Menulis artikel ilmiah menjadi kegiatan yang mudah dilakukan. Menggunakan strategi ini merupakan menerapkan kebiasaan baru yang inovatif dan kreatif. Awalnya kebiasaan menulis artikel itu harus dipaksakan. Pada akhirnya nanti akan menjadi kebiasaan dan bahkan ketagihan untuk menulis. Kalau sudah terbiasa menulis dan tidak menulis, maka akan merasa ada yang hilang dari kebiasaan yang pernah dilakukan. Menjadi penulis yang mahir harus menggunakan berbagai teknik menulis. Selain itu, juga harus menguasai teknik kebahasaan yang mumpuni. Menulis artikel ilmiah bagi mahasiswa merupakan hal yang biasa diterima sebagai tugas mata kuliah dari dosennya. Hal yang sangat ironis adalah ketika mengakui tulisan orang lain sebagai tulisannya dengan cara plagiasi. 
Akibatnya, semakin lama budaya menulis semakin menghilang karena efek pemanfaatan kecanggihan era modernisasi. Minat menulis di kalangan mahasiswa harus dibina secara serius dan hati-hati. Ketika itu dilaksanakan maka masiswa bersangkutan akan memiliki kemampuan yang mumpuni dan berkualitas.

Secara umum, tujuan penelitian ini adalah mendeskripsikan kemampuan mahasiswa dalam menulis artikel ilmiah dengan strategi mind mapping. Secara khusus, tujuan penelitian ini adalah mendeskripsikan kemampuan menulis mahasiswa dalam menulis judul, pendahuluan, pembahasan, pendahuluan, dan daftar pustaka artikel ilmiah dengan strategi mind mapping.

\section{METODE PENELITIAN}

Pendekatan

penelitian

ini menggunakan pendekatan kualitatif. Semua fakta, baik secara lisan, tulisan, dan nilai-nilai yang berasal dari sumber data manusia yang diamati, dicatat, didokumentasikan, dan dideskripsikan kemudian dikaji untuk menemukan makna temuan penelitian yang diperoleh.

Jenis penelitian ini menggunakan jenis penelitian deskriptif kualitatif. Peneliti ingin mendeskripsikan peningkatan kemampuan menulis judul, pendahuluan, pembahasan, penutup, dan daftar pustaka artikel ilmiah mahasiswa dengan penerapan strategi mind mapping. Pembuatan mind mapping dapat diselesaikan satu kali pertemuan. Pertemuan berikutnya dituangkan menjadi artikel ilmiah. Artikel ilmiah dapat diselesaikan dalam dua kali pertemuan. Data yang dikumpulkan dalam penelitian ini adalah data hasil belajar mahasiswa secara individual berupa artikel ilmiah. Mahasiswa yang dimaksud adalah mahasiswa IIB pengambil matakuliah Membaca Pemahaman, Prodi Pendidikan dan Sastra Indonesia, Fakultas Keguruan dan lilmu Pendidikan, Universitas Muhammadiyah Malang. Mahasiswa tersebut berjumlah 53 mahasiswa.

Peneliti menggunakan instrumen penjaring data. Instrumen penjaring data menjadi indikator dalam permasalahan yang diangkat dalam penelitian. Teknik analisis data dalam penelitian ini dilakukan secara deskriptif kualitatif.

\section{PEMBAHASAN}

\section{A. Kemampuan mahasiswa dalam} menulis Artikel IImiah pada Aspek Judul

Kemampuan mahasiswa dalam menulis artikel ilmiah dengan strategi mind mapping pada aspek penulisan judul menunjukkan kemenarikan, judul dengan isi sesuai, penulisan ejaan sesuai, dan diksi sesuai, menunjukkan isi artikel, makna khusus. Hal ini dapat dilihat pada hasil belajar mahasiswa pada penulisan judul artikel ilmiah seperti kutipan berikut ini.

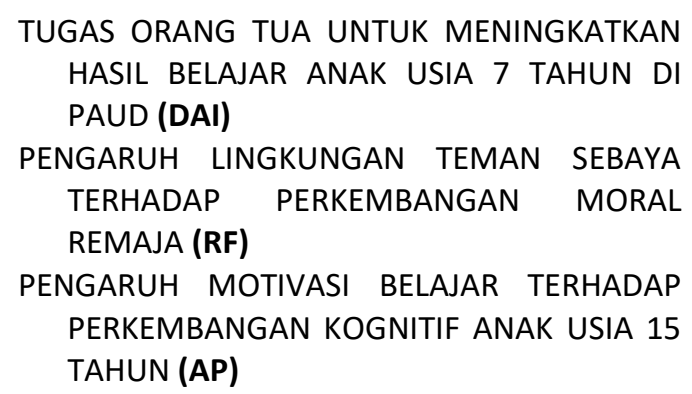
HASIL BELAJAR ANAK USIA 7 TAHUN DI PAUD (DAI)

PENGARUH LINGKUNGAN TEMAN SEBAYA TERHADAP PERKEMBANGAN MORAL REMAJA (RF)

PENGARUH MOTIVASI BELAJAR TERHADAP PERKEMBANGAN KOGNITIF ANAK USIA 15 TAHUN (AP) 
Musaffak dan Fida Pangesti. Penerapan Strategi Minp Mapping... Halaman 197-207 Jurnal Belajar Bahasa, ISSN 2502-5864, E-ISSN 2503-0329

Volume 3, No. 2, September 2018

PENGARUH KOMUNIKASI ORANG TUA
TERHADAP TUMBUH KEMBANG ANAK
(IWAN)
PERAN GURU DALAM MENINGKATKAN
PRESTASI SISWA DALAM INSTITUSI YANG
FORMAL (AR)
PENGARUH LINGKUNGAN MASYARAKAT
TERHADAP PERKEMBANGAN SOSIAL ANAK
USIA 13 TAHUN (MNC)

Judul-judul artikel pada kutipan di atas

(DAI, RF, AP, IWAN, AR, MNC) menunjukkan kemenarikan, judul dengan isi artikel sesuai, penulisan ejaan sesuai pedoman bahasa Indonesia, dan penggunaan diksi yang tepat. Diksi yang tepat (RF, AP, IWAN, AR) akan mempengaruhi kualitas tulisan dan gagasan-gagasan yang digunakan sesuai imajinasi pembaca. Selain itu, judul artikel juga menunjukkan kelengkapan isi artikel (DAI, RF, AP, IWAN, AR, MNC). Makna yang terkandung dalam judul artikel (DAI, RF, AP, IWAN, AR, MNC) bersifat khusus, sehingga pembaca merasa mudah dalam memahami pesan yang disampaikan oleh penulis. Ketepatan makna kata (DAI, RF, AP, IWAN, AR, MNC) sangat diperlukan bagi penulis untuk mengetahui sejauh mana keterkaitan antara bentuk kata yang dipilih dengan sumber kata. Katakata itu harus dilengkapi penjelas kalau memungkinkan. Judul-judul artikel di atas juga memperhatikan perkembangan kosakata (DAI, RF, AP, IWAN, AR, MNC) yang dipakainya, sehingga kosakata itu bisa dipahami oleh pembaca.

\section{B. Kemampuan mahasiswa dalam menulis Artikel IImiah pada Aspek Pendahuluan}

Kemampuan mahasiswa dalam menulis artikel ilmiah dengan strategi mind mapping pada aspek penulisan pendahuan menunjukkan kelengkapan isi, isi sesuai, gagasan runtut, penulisan ejaan sesuai, penulisan tanda baca sesuai, diksi sesuai, kalimat sudah efektif, dan paragraf padu. Hal ini dapat dilihat pada hasil belajar mahasiswa pada penulisan pendahuan artikel ilmiah seperti kyutipan berikut ini.

\section{A. Pendahuluan}

Masa remaja merupakan masa yang mana perkembangan fisiologis meningkat dan berdampak pada kematangan kelenjar endorin. Kematangan kelenjar berakibat pada kematangan seksual. Hal itu dianggap sebagai masa remaja sudah datang.

Batas awal dan akhir masa remaja sulit dipastikan. Setiap orang memiliki awal dan akhir masa remaja yang berbeda-beda. Namun penanda khusus awal dan akhir remaja dijadikan penentua masa anak-anak dan dewasa. Perubahan-perubahan fisik atau nonfisik menjadi penanda pokok dalam berubahan masa anak-anak ke remaja dan dewasa. Perubahan non-fisik dapat ditandai dengan perkembangan kognitif (intelektual), emosi, sosial, moral, dan kepribadian.

Lingkungan perkembangan anak sangat berpengaruh terhadap situasi atau kondisi anak. Lingkungan ini dapat berbentuk perkembangan fisik dan nonfisik. Fisik ketika masa anak-anak akan berpengaruh ketika masa remaja dan dewasa. Non-fisik (sosial) berpotensi akan mempengaruhi perkembangan individu secara signifikan. ... (GS)

Penulisan pendahuluan (GS) pada kutipan di atas sudah lengkap, isi artikel ilmiah sesuai, gagasan runtut, ejaan sesuai, dan tanda baca sesuai dengan pedoman bahasa Indonesia, diksi tepat, kalimat sudah efektif, dan paragraf sudah menunjukkan kepaduan. 


\section{Kemampuan mahasiswa dalam}

\section{Menulis Artikel IImiah pada Aspek} Pembahasan

Kemampuan mahasiswa dalam menulis artikel ilmiah dengan strategi mind mapping pada aspek penulisan pembahasan menunjukkan kelengkapan substansi permasalahan, urgensi masalah dengan isi sesuai, gagasan sudah runtut, penulisan ejaan sesuai, penulisan tanda baca sesuai, diksi sesuai, kalimat sudah efektif, dan paragraf sudah padu. Hal ini dapat dilihat pada hasil belajar mahasiswa pada penulisan pembahasan artikel ilmiah seperti kutipan berikut ini.

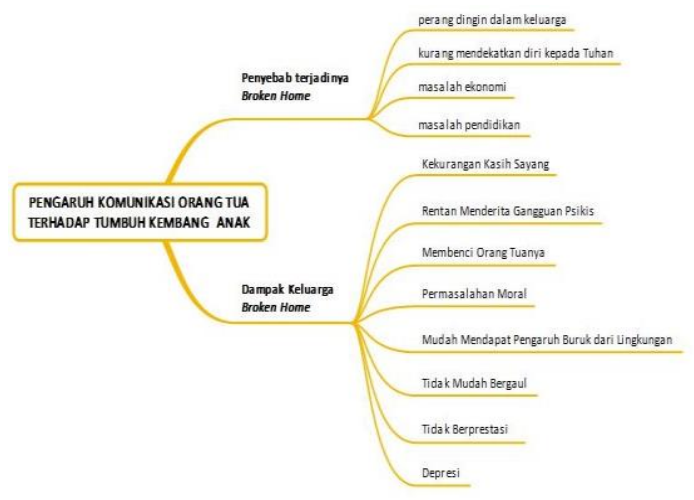

B. Pembahasan

1. Penyebab terjadinya Broken Home

Keluarga broken home merupakan keluarga yang sudah tidak lengkap lagi. Hal itu disebabkan karena salah satu orang tua atau kedua-duanya berpisah (bercerai) atau tidak hadir secara kontinyu dalam tenggat waktu yang cukup lama. Selain itu, keluarga broken home terjadi karena: (a) perselisihan antara suami istri; (b) tingkat keimanan yang kurang dan lebih mengedepankan kepentingan dunia; (c) ekonomi lemah berimbas pada pertenkaran dan perceraian; (d) masalah pendidikan merupakan salah satu penyebab perceraian karena ketidaktahuan mereka dalam mengurus anak dan mengambil keputusan dalam penyelesaian masalah keluarga (Sudarsono, 1990: 125). Oleh karena itu, solusi yang paling sesuai yaitu harus memiliki sikap saling percaya antarpihak, tidak ada yang saling menutupi, adil, menghargai atau saling melengkapi kekurangan masing-masing, dan saling menyayangi antara kedua belah pihak serta menghilagkan selisih paham yang menyebabkan perceraian.

\section{Dampak Keluarga Broken Home}

Menurut Ali dan Asrori (2004: 78), dampak keluarga broken home terbagi atas beberapa hal yang meliputi: minim kasih sayang, rentan berpengaruh pada psikis, sikap benci berlebih, miskin moral, dipandang negatif di lingkungan tempat tinggal, kesulitan dalam bergaul, minim prestasi, spiritual lemah, dan mudah depresi. Penjabaran selengkapnya sebagai berikut.

\subsection{Minim Kasih Sayang}

Suami istri dalam berumah tangga harus saling menyayangi dan harmonis. Dalam berumah tangga harus menghilangkan sikap egois antara suami istri. Saling menghargai harus muncul. Keduanya harus memiliki sifat terbuka dan adil. Sikap yang tidak harmonis, egois, tidak adil, dan tertutup akan berimbas pada anak. Jalan keluar setiap terjadi perselisihan antara suami istri harus ada. Perhatian kepada anak harus maksimal. Rumah tangga yang mengalami broken home akan berimbas kepada sekitarnya. Ego antarpasangan harus ditangani.

\subsection{Rentan Menderita Gangguan Psikis}

\subsection{Membenci Berleboih}

2.4 Miskin Moral

...

2.5 Dipandang Negatif di Lingkungan Tempat Tinggal

2.6 Sulit Bergaul

2.7 Minim Prestasi

...

2.8 Spiritual Lemah

...

2.9 Depresi

Penulisan pembahasan (LS) pada kutipan di atas menunjukkan kelengkapan substansi permasalahan, urgensi masalah 
dengan isi sesuai, gagasan sudah runtut, ejaan sesua, tanda baca sudah sesuai dengan pedoman bahasa Indonesia, diksi sudah tepat, penulisan kalimat sudah efektif, dan paragraf sudah padu.

\section{Kemampuan mahasiswa dalam}

\section{menulis Artikel Ilmiah pada Aspek}

\section{Kesimpulan}

Kemampuan mahasiswa dalam menulis artikel ilmiah dengan strategi mind mapping pada aspek penulisan kesimpulan menunjukkan bahwa substansi permasalahan lengkap, isi dengan intisari permasalahan sesuai, gagasan runtut, penulisan ejaan sesuai, penulisan tanda baca sesuai, diksi sesuai, kalimat sudah efektif, kohesi, dan koherensi. Hal ini dapat dilihat pada hasil belajar mahasiswa pada penulisan kesimpulan artikel ilmiah seperti kutipan berikut ini.

\section{PENUTUP}

\section{Kesimpulan}

Penceraian orang tua berpengaruh besar terhadap pertumbuhan anak, karena keluarga yang utuh menentukan kualitas anak menjadi baik dan keluarga broken juga menentukan kualitas anak menjadi buruk jika penanganannya kurang tepat. Emosi anak kurang stabil atau mereka belum bisa mengendalikan emosi yang berpengaruh besar terhadap kelangsungan hidup mereka. Emosi anak-anak yang tidak terkontrol maka rata-rata anak akan melampiaskan dalam bentuk perbuatan negative. Hal ini akibat dari stress atau depresi berat yang dialami anak dan tidak adanya tempat mencurahkan segala keluh kesah. Oleh karena itu, dibutuhkan dukungan yang kuat dari orang-orang terdekat seperti keluarga, teman sejawat, guru, atau tokoh agama yang dipercaya. (LS)
Penulisan kesimpulan pada kutipan di atas (LS) menunjukkan bahwa kelengkapan substansi permasalahan, terdapat kesesuaian antara isi dengan intisari permasalahan, gagasan runtut, penulisan ejaan dan tanda baca sesuai dengan pedoman bahasa Indonesia, penggunaan diksi tepat, penulisan kalimat sudah efektif, kohesi, dan koherensi.

\section{E. Kemampuan mahasiswa dalam menulis Artikel Ilmiah pada Aspek Daftar Pustaka}

Kemampuan mahasiswa dalam menulis artikel ilmiah dengan strategi mind mapping pada aspek penulisan daftar pustaka meningkat. Hal itu dapat dilihat pada daftar pustaka yang menunjukkan dalam penulisan ejaan sesuai, penulisan tanda baca sesuai bahasa Indonesia, kesesuaian dengan penulisan daftar pustaka, dan kelengkapan unsur penulisan daftar pustaka. Hasil belajar mahasiswa pada penulisan daftar pustaka artikel ilmiah dapat dilihat pada kutpan berikut ini.

\section{Daftar Pustaka}

Coulhoun, J. F. dan Acocella, J. R. 2011. Psikologi. Semarang: IKIP Press.

Hurlock, E. B. 2002. Psikologi: Suatu Perkembangan Anak. Jakarta: Erlangga.

Monks, F. J., Knoers, A. M. P. dan Haditono, S. R. 2001. Psikologi Perkembangan: Suatu Pengantar. Yogyakarta: Gadjah Mada Press. (NF)

Ali, Muhammad dan Asrori, Muhammad. 2004. Psikologi Remaja. Jakarta: Bumi Aksara.

Kartono, K. 2000. Psikologi Anak. Bandung: Rosda.

Sjarkawi. 2006. Kepribadian Anak. Jakarta: Bumi Aksara. 
Sudarsono. 2009. Kenakalan Remaja Masa Kini. Jakarta: Rineka Cipta. (DAI)

Penulisan daftar pustaka pada kutipan di atas (NF, DAI) menunjukkan kesesuaian dengan penulisan ejaan bahasa Indonesia, kesesuaian dengan penulisan tanda baca bahasa Indonesia, kesesuaian dengan penulisan daftar pustaka, dan kelengkapan unsur penulisan daftar pustaka.

\section{SIMPULAN}

Kemampuan mahasiswa dalam menulis judul artikel, pendahuluan artikel, pembahasan artikel, penutup artikel, dan daftar pustaka artikel dengan penerapan strategi mind mapping meningkat. Berikut penjabaran selengkapnya.

Pertama, penulisan judul menunjukkan kemenarikan, judul dengan isi sesuai, penulisan ejaan sesuai, dan diksi tepat, isi artikel sesuai, dan bermakna khusus sesuai tema.

Kedua, penulisan pendahuluan lengkap, isi sesuai, gagasan runtut, penulisan ejaan sesuai, penulisan tanda baca sesuai, diksi sesuai, kalimat sudah sesuai, dan paragraf sudah padu.

Ketiga, penulisan pembahasan menunjukkan kelengkapan substansi permasalahan, kesesuaian antara urgensi masalah dengan isi, gagasan runtut, penulisan ejaan sesuai, penulisan tanda baca sesuai, diksi sesuai, kalimat sudah efektif, dan paragraf sudah padu.

Keempat, penulisan kesimpulan menunjukkan kelengkapan sesuai substansi permasalahan, kesesuaian isi dengan intisari permasalahan, gagasan runtut, penulisan ejaan sesuai, penulisan tanda baca sesuai, diksi sesuai, kalimat sudah efektif, kohesi, dan koherensi.

Kelima, penulisan daftar pustaka menunjukkan penulisan ejaan sesuai, penulisan tanda baca sesuai, penulisan daftar pustaka sesuai pedoman, dan unsur penulisan daftar pustaka lengkapan.

\section{DAFTAR RUJUKAN}

Abdurrahman, A. (2000). Quantum Leaming: Membiasakan Belajar Nyaman dan Menyenangkan. Bandung: Kaifa.

Adnan, Z. (2005 ). Merebut Hati Audiens Intemasional: Strategi Ampuh Meraih Publikasi di Jurnal Ilmiah. Jakarta: Gramedia Pustaka Utama.

Bermawy, \& dkk (Penyunt.). (2009). Active Learning: 101 Strategi Pembelajaran Aktif. Yogyakarta: Pusaka Insan Madani.

Blumner, J. (2008). Beyond the Reactive: WAC Programs and the Steps Ahead dalam Joumal on Writing Across the Curriculum. Michigan, USA: University of Michigan.

Haryanto, \& dkk. (2000). Metode Penulisan dan Penyajian Karya Ilmiah: Buku Ajar untuk Mahasiswa. Jakarta: Buku Kedokteran EGC.

Indriati, E. (2006). Menulis Karya Ilmiah: Artikel, Skripsi, Tesis, dan Disertasi. Jakarta: Gramedia Pustaka Utama.

Kellog, R. (2008). Training Writing Skills: $A$ Cognitive Developmental Perspective Journal of Writing Research. . USA: Department of Psychology, Saint Louis University. 
Musaffak dan Fida Pangesti. Penerapan Strategi Minp Mapping... Halaman 197-207 Jurnal Belajar Bahasa, ISSN 2502-5864, E-ISSN 2503-0329

Volume 3, No. 2, September 2018

Nasucha, Y., Rohmadi, M., Wahyudi, A., \& Kusumawati, Y. (2009). Bahasa Indonesia untuk Penulisan Karya Tulis Ilmiah: Mata Kuliah Wajib Pengembangan Kepribadian. Yogyakarta: Media Perkasa.

Sudarmanto, Y. (Penyunt.). (2007). Bahasa Indonesia Mata Kuliah Pengembangan Keprbadian di Perguruan Tinggi. Jakarta: Grasindo.
Supadi, d. (2007). Fokus Menyelesaikan Soal-soal Ujian Nasional SMP. Jakarta: PT Kawan Pustaka.

Susi, P. (Penyunt.). (2010). Buku Pintar Mind Map. Jakarta: Gramedia.

Tim Dosen UM. (2010). Pedoman Penulisan Karya Ilmiah: Skripsi, Tesis, Disertasi, Artikel, Makalah, Tugas Akhir, Laporan Penelitian. Malang: Universitas Negeri Malang. 